\title{
Mentorprogram az Óbudai Egyetemen
}

\section{Réger Mihály}

\author{
az Óbudai Egyetem, Bánki Donát Gépész és Biztonságtechnikai Mérnöki Kar \\ egyetemi tanára \\ reger.mihaly@uni-obuda.hu
}

Az értékes szakmai tudást szerzett és az oktatóival elégedett hallgató a legjobb reklámhordozója a felsőoktatási intézményeknek. Ezzel szemben a kutatási teljesitmény általában nagyobb súllyal esik latba az oktatói elóléptetésnél. Vezetőként arra törekedtem, hogy egyetemünkön egyaránt értékesnek tekintsük a tudományos és az oktatási tevékenységet. Intézményfejlesztési tervünkben ezért külön területként jelent meg az oktatói munka minőségének fejlesztése. Az oktatók hallgatói véleményezéséből származó adatokat évtizedek óta gyüjtjük és elemezzük. Ezek alapján világossá vált, hogy a tantermi teljesítmény, az oktatói-hallgatói viszony nem függ az akadémiai rangtól, továbbá az egyes oktatók megitélésében az évek során nem következett be számottevő változás a rendszeres visszajelzések hatására sem. Hatékonyabb eljárásokat keresve került látóterünkbe a mentorálás, amelynek tanári munka fejlesztésében elért eredményei közoktatási környezetben már bizonyíthatók voltak. Különböző célcsoportokat azonositottunk: az újonnan belépő és kezdő oktatókat, a tanári munkájukról szakértői visszajelzést igénylöket és az erösen negatív hallgatói megítélésú, szerepükben küszködő oktatókat. Nem csak az igényeiknek megfeleló programokat és támogatási formákat dolgoztunk ki, hanem ezeknek az egyetem múködésébe való beépitését is megvalósitottuk szabályzataink módositásával. Egyetemi szintú rendszerré válását a legkiválóbb oktatók közül kiválasztott kari mentorok felkészitésével és munkába állitásával biztositottuk. Az elért eredmények kézzel foghatók. Ugyanakkor a rendszer stabilizálásának feltételeit - például a kari mentorok munkájának honorálását, állandó szupervízióját - nem sikerült maradéktalanul biztosítani, ami veszélyezteti e hasznos innováció fennmaradását.

Kulcsszavak: felsőoktatási mentorálás, tapasztalt és kezdő oktatók mentorálása, egyetemi mentorálási rendszer, oktatók hallgatói véleményezése

DOI: 10.37205/TEL-hun.2020.1-2.07

Az egyetemi értékteremtés a tantermekben, a laboratóriumokban, az oktató és tudományos munkában valósul meg, a hallgatók és az oktatásban, nevelésben közremúködő munkatársak együttmüködésében. Az óvodától a középiskoláig törvényben rögzített elvárás, hogy valamilyen pedagógiai képzettséggel rendelkezzenek az oktatással, neveléssel foglalkozó munkatársak. A felsőoktatásban az 
oktatói státuszban dolgozókkal szemben nem elvárás a pedagógiai képzettség. A tudományterületén kiváló szakemberként ismert oktatók egy része küszködik a tanári szerepben. Az oktatói teljesítményértékelésben és előlépésben pedig általában nagyobb súllyal esik latba a tudományos, mint a katedrán nyújtott teljesítmény.

Rektori pályázatom megfogalmazása során áttekintettem az egyetem versenyképességének humán feltételeit. Az egyik feltétel a tudományban jelentős eredményt felmutató szakemberek megtartása, illetve kiválasztása a pályázók közül. A másik, sokáig nem kellően értékelt feltétel, a tanári/oktatói szerepben nyújtott teljesítmény elismerése, amelynek fajsúlyos indikátora a hallgatók véleménye, elégedettsége.

Az Óbudai Egyetem felelős vezetőjeként annak az alapvető célnak a megvalósítása mellett köteleztem el magam, hogy a vezetés az egyetemi dolgozókból az adott cél mellett elkötelezett, minőségi munkát végző, ugyanakkor összetartó egyetemi kollektívát hozzon létre. Olyan kollektívát, amelynek minden tagja érti és érzi saját feladatának jelentőségét, felelősségét és értelmét. Ideális esetben minden dolgozónak tudnia és éreznie kell, hogy vele szemben reális és határozott elvárások vannak, azt, hogy ezeknek az elvárásoknak minőségi oktatói munka felmutatásával meg tud felelni, van értelme a tevékenységének, és látja, megtalálja a helyét az egyetem szervezetében.

Amikor a felsőoktatási intézmények versenyeznek a hallgatókért, az egyetem jó híre jelentős vonzerőt gyakorol a jelentkezőkre. A jó hírű és kurrens tudást kínáló egyetemekre többen jelentkeznek, magasabbak a felvételi pontszámok, válogathatnak a tehetségesebb jelentkezők között. Az egyetem jó hírének első számú humán feltétele az oktatói minőség. A szakterületén értékes tudást szerzett és az oktatóival (és egyben az egyetemmel) elégedett hallgató a legjobb reklámhordozója az intézménynek.

Minden egyetemi munkatárs irányában alapelvárás a minőségi munkavégzés, de az egyén szintjén az életfeladat betöltésének érzése is kapcsolódóik a jól végzett munkához és az általa kiváltott elégedettséghez. Ez természetesen sok tényező függvénye, melyek közül talán a legfontosabb, hogy a munkatársak számára egyaránt becsülendő és értékes legyen a tudományos és az oktatási tevékenység is. Az oktatói és kutatói-szakmai szerepek harmonikus betöltése tehát alapvető jelentőséggel bír az egyetem egész múködése szempontjából. Ez a felismerés indukálta azt, hogy az egyetem intézményfejlesztési tervéhez kapcsolódó akciótervben 
külön fejlesztési területként jelenítsük meg az oktatásban nyújtott teljesítményt, az oktatói/tanári minőséget.

Intézményünkben több évtizedes hagyománya van az oktatók hallgatói véleményezésének, és abban bízva, hogy az egyetemi oktatók számára fontosak, fejlődésükhöz iránymutatók a hallgatók visszajelzései, rendszeresen megkapják az eredményeket közvetlen vezetőiktől. A hallgatói véleményeket évekig gyüjtöttük és elemeztük. Világossá vált, hogy a tantermi teljesítmény, az oktatói-hallgatói viszony nem függ az akadémiai rangtól. Kiderült, hogy az egyes oktatók megítélésében az évek során nem következett be számottevő változás még a rendszeres visszajelzések hatására sem. Bár a bírálatok komoly feszültséget okoztak, az oktatói tevékenységbe való beépítésük, a tantermi munka fejlesztése, csiszolása szakértő támogatás nélkül - rendre elmaradt.

Nem várhattuk el minden érintett oktatótól, hogy beiratkozzon egy több évig tartó pedagógiai vagy tanári képzésre. Hatékonyabb és gyorsabb fejlesztő eljárást kellett keresnünk a tanári teljesítmény fejlesztésére. Áttekintve az egyetem belső lehetőségeit, felfigyeltünk a tanári minőség fejlesztésével foglalkozó publikációkra (Suplicz, 2011; Füzi, 2011, 2007), amelyek a mentorálásban vélték felfedezni az oktatói hatékonyság növelésének módszerét.

A kutatók bevonásával kialakítottunk egy rendszert, amelynek célja az oktatók munkájának rendszerszerü, akár személyre szabott támogatása.

Különböző célcsoportokat azonosítottunk:

- újonnan belépő és/vagy kezdő oktatók,

- tanári munkájukról szakértői visszajelzést igénylők,

- erősen negatív hallgatói megítélésű, szerepükben küszködő oktatók.

Az oktatói munka fejlesztésére kialakított rendszerünk főbb elemei az alábbiak lettek:

1. Az újonnan belépő oktató kollégák számára készült egy rövid, lényegre törő, derűs hangulatú, felsőoktatás-pedagógiai útmutató a tanárképzésért felelős központunk munkatársainak közreműködésével. Ez összefoglalja, melyek a legfontosabb szemléleti elemek, módszerek, amelyeket új oktatóink figyelmébe ajánlunk.

2. Sor került az oktatók hallgatói véleményezési rendszerének felülvizsgálatára és átalakítására. Az átalakított hallgatói kérdőívekkel gyűjtött információk alkalmasak arra, hogy bemutassák a kollega támogatási rendszerbe való bevonásának szükségességét, és megalapozzák a mentorálási fo- 
lyamat felkínálásáról szóló döntést. Továbbá alkalmasak arra is, hogy kijelöljék az esetleges mentori tevékenység főbb irányait.

3. Oktatói szerepfejlesztő tréningeket dolgoztak ki szakértőink, amelyeket minden félévben meghirdettünk, és önkéntes jelentkezés alapján elérhetővé tettünk valamennyi oktatással foglalkozó munkatársunk számára. A tréningeket óralátogatások és óraelemzések előzték meg, így a tréningek tartalma és témái a résztvevők igényeinek, egyéni nehézségeinek megfelelően alakíthatóvá váltak.

4. Kialakítottuk az oktatók mentorálásának személyi feltételeit. Felsőoktatási mentorokat képeztünk ki minden karon, valamint megteremtettük a mentorok munkáját támogató szupervízió rendszerének alapjait.

5. A rendszer mủködtetéséhez szükséges elemeket rögzítettük egyetemünk szabályzataiban, például az oktatók hallgatói véleményezésének rendszerét és annak következményeit. A gyengén teljesítő oktatók számára erősen ajánlottá tettük a mentori segítség igénybevételét.

A tanári szerepfejlesztő tréninget a mentorálás előszobájaként is definiáltuk. Aki csupán visszajelzést szeretett volna kapni az órái pedagógusszakmai megítéléséről, vagy inspirálódni akart a tréning során megismert jó gyakorlatokból, esetleg a kutatások alapján bemutatott hallgatói elvárásokból, annak számára ez elegendő lehet a fejlődéshez.

Akinek viszont közepesnél gyengébb volt (ötfokú skálán 3.00 alatti) a diákvéleményekben mért átlaga, annak ajánlottá vált a mentori segítség igénybevétele. $\mathrm{A}$ szervezeti és múködési szabályzatban - ötfokú skálákon mért hallgatói véleményekre támaszkodva - definiálnunk kellett az érintett oktatók körét az alábbiak szerint.

„A kiemelkedően rossz hallgatói vélemények alapján a kar dékánjának, az intézet igazgatójának mentori segítséget kell felajánlania az oktatónak. Amennyiben az oktató önfejlesztő munkája egy féléven belül nem hoz számottevő pozitív változást, akkor az intézet igazgatójának az oktatót köteleznie kell mentori támogatás igénybevételére és a vele való együttmüködésre. Amennyiben a mentorálás három félévet követően sem eredményez a hallgatói véleményekben is mérhető számottevő javulást - vagyis az eredmények továbbra sem érik el a minimálisan elfogadható 3,00 átlagot -, akkor az intézet igazgatójának az oktatót más, nem oktatási tevékenységgel kell megbíznia, vagy kezdeményeznie kell az oktató foglalkoztatásra irányuló jogviszonyának megszüntetését." 
A kutatókat már korábban megbíztuk, hogy képezzenek ki karonként legalább két mentort, akik a hallgatói vélemények alapján mérsékelt teljesítményt nyújtó oktatókat személyre szabottan segítik. Vezetésem alatt, 2019 júniusáig, húsz egyetemi mentort képeztünk ki. A mentorok munkájának koordinálásával és szupervíziójával a képzésüket végző oktató kollégákat bíztuk meg. Így a formális, kvázi felettesi kapcsolat egybeesett a szakmai támogató szereppel. Egy pályázat keretében 2020 márciusáig még zajlik újabb mentorok kiképzése, illetve tanári szerepfejlesztő tréningek tartása. Igen fontosnak tartom, hogy mentori szerepre csak a 4.00-nél jobb hallgatói véleményezési átlageredménnyel rendelkező oktatókat választottuk ki és kértük fel. Olyan kollégákat képeztünk mentorrá, akiknek tantermi gyakorlata sikeres, hallgatókkal kialakított kapcsolata harmonikus, ezért jó mintává válhatnak mentoráltjaik számára.

Ez a rendszer már 2018-ban meghozta első eredményeit. A rendszer stabilizálását és továbbfejlesztését, például a mentori hálózat hatékony működésének feltételeit viszont nem sikerült biztosítani. A mentorok motivációjának fenntartását anyagi és/vagy órakedvezmény formájában történő megbecsülésüktől, valamint a mentorok szakmai felügyeletét és koordinálását ellátó szakember alkalmazásától remélhetjük. Amennyiben ezeket a feltételeket biztosítani tudja az egyetem, akkor fennmaradhat a hálózat, és továbbra is segítséget kaphatnak a tanári szereppel küszködő és a hallgatói véleményezésben alacsony pontszámot elérő oktatók. Ha nem, akkor előbb formálissá válik, majd az eredmények elmaradása miatt megszűnhet ez a hasznos innováció.

A mentorprogram és a tanári szerepfejlesztő tréningek sikerét a fentebb említett kutatások alapozták meg, ugyanakkor megítélésem szerint alapvető fontosságú, hogy a program megvalósítását felkészült és főleg hiteles munkatársak végezzék az emberi méltóság és a személyiségi jogok maximális tiszteletben tartása mellett. A tréningek csak akkor érik el a céljukat, ha őszinte, diszkrét, humánus, támogató légkörben zajlanak, mert az oktatói szerepet és a személyiséget is érintő fejlesztés bizalmi légkört igényel.

A programnak volt egy előre nem tervezett pozitív hatása is. A hallgatói vélemények alapján legjobbnak tartott és mentornak felkért kollégáink megtiszteltetésként, munkájuk elismeréseként élték meg a felkérést. A különböző szakterületről és karról érkezett oktatók, mérnöktanárok, tanársegédek, adjunktusok, docensek egymást is támogató közösséggé váltak a tréningek során. A jó gyakorlatok 
megosztása során megerősödött a korábbi tapasztalat: az akadémiai rangtól függetlenül lehet valaki jó tanári adottságokkal rendelkező, tehetséges oktató.

A fejlesztő programon részt vett munkatársainktól visszajelzést kértünk a tréningek hasznosságát illetően. A tréningekkel kapcsolatos visszajelzések szinte kivétel nélkül pozitívak voltak, eredményességüket, a befejeződött mentorálásoknál a hallgatói vélemények is visszaigazolták.

\section{Irodalom}

Fűzi, B. (2011). Tanárok mentorálásának gyakorlata. DSGI Ergonómiai Mérnöki Iroda.

Fúzi, B. (2007). Tanárok iskolai élményeinek szerepe a pedagógiai munka sikerességében. Alkalmazott pszichológia, 9(3-4) 5-23.

Suplicz, S. (2011). Tanárok mentorálásának elméleti alapjai. DSGI Ergonómiai Mérnöki Iroda. 


\section{Mentoring program at the Óbuda University}

Students who have gained valuable professional knowledge and are satisfied with their instructors are the best advertising medium for higher education institutions. In contrast, research performance tends to be more important in a university instructor's career. As a leader, I have sought to make both scientific and educational activities valuable for our university staff. Therefore, the improvement of the quality of teaching appeared as an emphasized area in our institution's development.

We have been analyzing data from the assessment of instructors' work by students for decades. Based on these, it became clear that the classroom performance does not depend on the academic rank, and there has been no significant change in the assessment of individual lecturers over the years because of regular feedback. In search of more efficient procedures, mentoring came into our field of vision, its results in the development of teacher work were proved in public education.

We identified different target groups: new entrants and beginners, instructors who require expert feedback on their work, and lecturers who have a markedly negative student assessment and struggle with their role. We have developed programs and different forms of support that meet the target groups' needs, furthermore, we have implemented the mentoring program into the operation of the university by amending our regulations. We ensured that the mentoring program became a university-level system by training faculty mentors selected from the best lecturers.

The results achieved are visible. However, the conditions for stabilizing the system - e. g. the remuneration and constant supervision of the work of the faculty mentors - have not been fully ensured, which jeopardizes the survival of this useful innovation.

Keywords: mentoring in higher education, mentoring of new and experienced university teachers, mentoring system, students' evaluation of teachers' work 